\title{
APLIKASI PROGRAM DINAMIK PADA METODE PELAKSANAAN PENGECORAN PLAT LANTAI
}

\author{
Agung Sedayu \\ Jurusan Teknik Arsitektur Fakultas Sains dan Teknologi UIN Maulana Malik Ibrahim Malang \\ Mahasiswa Program Doktor Teknik Sipil Universitas Brawijaya Malang
}

\begin{abstract}
The development of world construction projects at this time that established by widespread methods of physical implementation which more excellent and sophisticated. The contractors are competing to obtain optimum results, and reduce losses more lower. The results obtained should not give benefit one person only, the other one should not to lose and suffer. Islam guides human how they work give benefit to their own and others. Many methods, equipment, and expertise deployed by the contractor for their work more optimal, one method for optimizing the physical implementation of the project is Dynamic Programming. Dynamic Programming to solve the problem optimization is not only with one step, but the events that took place linked to each other. Case study in this paper is the application of dynamic programming of implementation method of concrete casting on floor slab of Green House building, it's belongs to Department of Biology, UIN Maliki Malang with backward induction phase. In modern century as this era has many fast-growing method of implementation that are categorized as advanced, but the problem that the methods actually optimal in terms of cost and time, due to cost and time parameters are very important in the progress of construction projects. The methods is very sophisticated so make project to be done very fast but it is very expensive financing, or the method is still conventional and traditional so that project costs will be reduced as cheaply, but the project need long time to be finished. Where is the decision that one will be expected to demand that we use what method. Mathematical formulas of dynamic programming as recursive equation with change big problem into smaller sub-problems, so the completion of smaller problems will be found solving of the original problem. Optimization process in this case that slab casting which solved in two methods, manually calculations with a recursive formula and use software DS Win 2.0. Optimization result of the two method are compared, and the two method produce similar results. Optimal or not parameter of the two method is optimum time and cost.
\end{abstract}

Keywords: Dynamic Programming, Project Implementation Method, Floor Slab Casting

\section{PENDAHULUAN}

Sabda Rasululloh saw, "Sesungguhnya Allah sangat mencintai orang yang jika melakukan sesuatu pekerjaan dilakukan secara itqan (tepat, terarah, jelas, dan tuntas)." (HR Thabrani)

Dari hadits di atas kita dianjurkan dalam melakukan tugas dan pekerjaan sehari-hari hendaknya dilakukan dengan itqan yakni sistematis, rapi, tepat sasaran, jelas, selesai tepat waktu, dan dapat memberikan manfaat, artinya manfaat bukan sesuatu pekerjaan yang sia-sia (Hafidhuddin \& Tanjung, 2005:24). Di dalam pekerjaan implementasi fisik proyek konstruksi, indikator itqan ini sangatlah penting dan benarbenar ditegakkan, agar mendapat ridlo Allah swt dan memberi manfaat bagi kemaslahatan bagi diri sendiri dan orang lain. Di jaman modern sekarang ini, banyak sekali metode pelaksanaan yang digunakan, salah satunya adalah dengan rumus matematika program dinamik.

Pemrograman dinamik adalah cara pengambilan keputusan dengan melibatkan tahapan-tahapan secara berurutan (Aminudin, 2005:22). Pemrograman dinamik menyelesaikan permasalahan optimasi tidak dengan sekali langkah, namun dengan mengubah masalah yang cukup besar ke dalam sub masalah yang lebih kecil, sehingga dari rangkaian penyelesaian masalah yang lebih kecil akan ditemukan penyelesaian masalah aslinya (Taha, 1997:79). Pada contoh kasus kali ini adalah penerapan progam dinamik pada metode pelaksanaan pengecoran plat lantai gedung Green House Jurusan Biologi UIN Maliki Malang (Gambar 1 - 4) dengan metode induksi mundur. Di era modern saat ini telah banyak berkembang pesat metode pelaksanaan yang tergolong mutakhir, namun persoalannya adalah apakah metode tersebut benar-benar optimal dari segi biaya dan waktu, karena parameter biaya dan waktu sangat penting dalam kemajuan proyek konstruksi (Soeharto, 1999:102). Metodenya canggih sehingga proyek cepat selesai namun secara pembiayaan sangat mahal, atau sebaliknya metodenya masih konvensional atau tradisional 
yang berdampak biaya ditekan semurah mungkin, namun proyek selesainya lama.

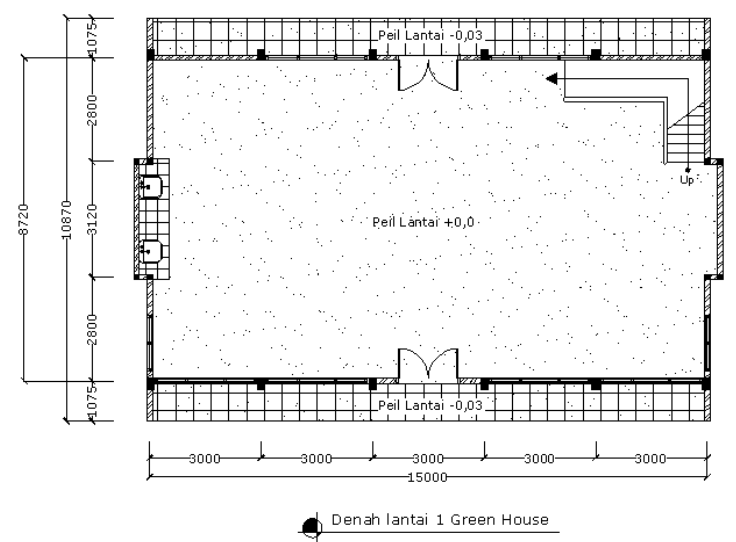

Gambar 1. Denah Lantai 1 Green House

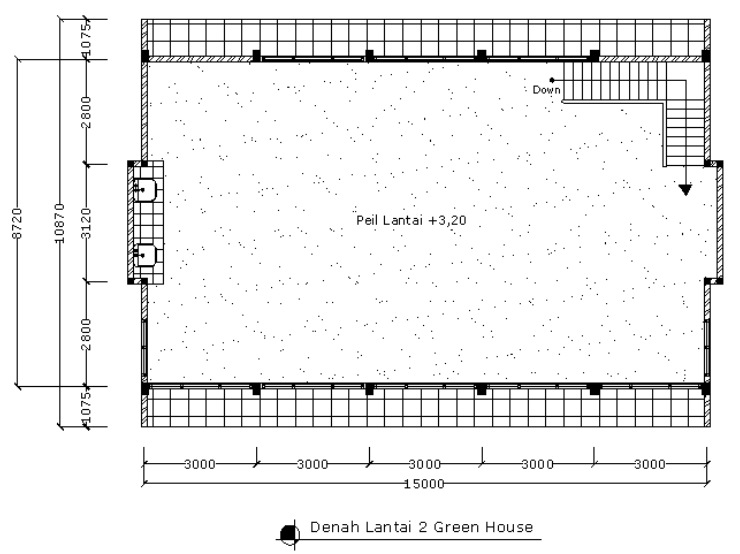

Gambar 2. Denah Lantai 2 Green House

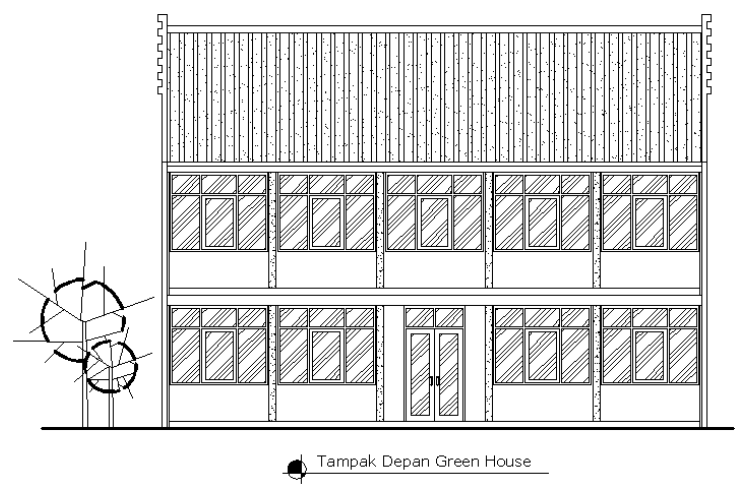

Gambar 3. Tampak Depan Green House

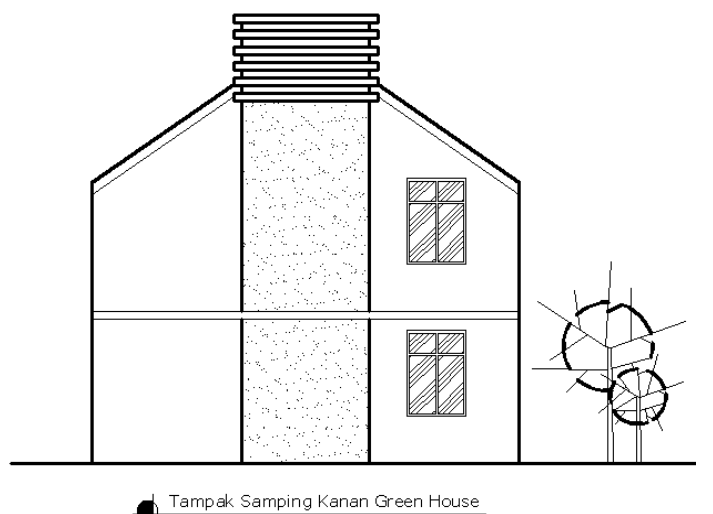

Gambar 4. Tampak Samping Kanan Green House

\section{PROGRAM DINAMIK}

Program dinamik (Dynamic Programming) adalah suatu teknik untuk menyelesaikan masalah yang melibatkan sekumpulan keputusan yang saling berhubungan dalam tujuan agar secara keseluruhan mencapai keaktifannya (Mulyono, 2004:77). Beberapa istilah yang digunakan dalam penyelesaian masalah program dinamik adalah :

1. Stage, langkah pertama adalah mengidentifikasikan stage atau tahapan dalam proses keputusan. Misalnya, terdapat (n) tahapan yang diberi label 1, 2, 3, 4, .., n-1, n.

2. States, adalah tahapan yang menggambarkan status semua informasi dalam membuat keputusan. Misalnya, jika dalam stage 3 terdapat state 5 , maka ditulis dengan $s_{3}=5$

3. Decision, variable keputusan atas stage I ditulis dengan $d_{i}$. Misalnya dalam stage 3 terdapat states 5 , maka $\mathrm{d}_{3}$ mungkin sama dengan 7 atau 8 ( menuju states 7 atau 8).

4. Return Function. Untuk menghitung efektivitas digunakan fungsi dengan notasi $\mathrm{f}$ yang dapat berupa biaya, laba, jarak, atau beberapa hitungan yang lain. Fungsi f tersebut dinamakan Return Function, misalnya, $f_{i}\left(s_{i} d_{i}\right)$. Apabila nilai $f_{i}$ optimum ditulis dengan $f_{i}^{*}\left(s_{i}\right)$ atau dikenal dengan istilah Optimum Return Function. Misalnya, dalam stage 2 terdapat stages 2 atau $\mathrm{I}=2$, dan $s_{\mathrm{i}}=2$, maka fungsinya ditulis :

$$
\begin{aligned}
\mathrm{F}_{2} & =\min \mathrm{f}_{2}\left(2, \mathrm{~d}_{2}\right) \mathrm{d}_{2} \\
& =\min \left\{\mathrm{f}_{2}(2,4), \mathrm{f}_{2}(2,5), \mathrm{f}_{2}(2,6)\right\}
\end{aligned}
$$

5. Recursions, $\mathrm{f}_{\mathrm{i}}^{*}\left(\mathrm{~s}_{\mathrm{i}}\right)=\min \left\{\mathrm{D}\left(\mathrm{s}_{\mathrm{i}}, \mathrm{d}_{\mathrm{i}}\right)+\mathrm{f}_{\mathrm{i}+1} *\left(\mathrm{~d}_{\mathrm{i}}\right)\right\}$

\section{ANALISIS BIAYA PELAKSANAAN}

Untuk menunjang dan memperjelas optimasi metode pelaksanaan yang mana yang lebih menguntungkan, maka terlebih dahulu dilakukan analisis biaya pelaksanaan pengecoran plat lantai pada setiap stages dan states, sebagai berikut :

\section{Stage $3(n=3)$, merupakan Tahap Persiapan Pengecoran.}

Tahap ini merupakan tahap persiapan yang mencakup kordinasi dan perencanaan, dengan biaya pelaksanaan masuk biaya tak langsung (overhead) dengan satuan Lump Sum (Ls) (Soeharto,2001:50) sebesar Rp. 500.000,00 dengan durasi waktu 1 hari.

2. Stage $2(n=2)$, merupakan Tahap Pembuatan dan Pemasangan Bekesting

Tahap ini merupakan tahap pemasangan dan pembuatan bekesting, yang terdiri dari 2 pilihan langkah, meliputi : 
a. Pemasangan bekesting dengan perancah bambu.

Pekerjaan pembuatan bekesting ini ditunjang oleh perancah bambu. Analisis

Tabel 1. Analisis Biaya Pekerjaan Stage $2(n=2)$ kegiatan pemasangan bekesting dengan perancah bambu

\begin{tabular}{|c|c|c|c|c|c|c|}
\hline No & Item Pekerjaan & Volume & Satuan & Koefisien & Harga Satuan & Jumlah \\
\hline 1 & Bambu & 140 & btg & & Rp. $17,500.00$ & Rp2,450,000.00 \\
\hline 2 & $\begin{array}{l}\text { Kayu meranti reng } \\
2 \mathrm{~cm} \times 3 \mathrm{~cm} \times 4 \mathrm{~m}\end{array}$ & 0.048 & $\mathrm{~m} 3$ & & Rp. 3,505,000.00 & Rp $168,240.00$ \\
\hline 3 & \begin{tabular}{|l|} 
Kayu kasau \\
$4 \mathrm{~cm} \times 6 \mathrm{~cm} \times 4 \mathrm{~m}$ \\
\end{tabular} & 0.288 & m3 & & Rp. 4,250,000.00 & Rp 1,224,000.00 \\
\hline 4 & Paku 7,5 cm & 7.5 & $\mathrm{~kg}$ & & Rp. $12,500.00$ & $\mathrm{Rp} \quad 93,750.00$ \\
\hline 5 & Paku $4 \mathrm{~cm}$ & 5 & $\mathrm{~kg}$ & & Rp. $9,750.00$ & $\mathrm{Rp} \quad 48,750.00$ \\
\hline 6 & Upah Mandor & 1 & $\mathrm{Oh}$ & 2.1125 & Rp. $65,000.00$ & $\operatorname{Rp} 137,312.50$ \\
\hline 7 & Upah tukang & 2 & $\mathrm{Oh}$ & 3.25 & Rp. $55,000.00$ & $\mathrm{Rp} \quad 357,500.00$ \\
\hline 8 & Upah pekerja & 5 & $\mathrm{Oh}$ & 3.25 & Rp. $40,000.00$ & $\mathrm{Rp} \quad 650,000.00$ \\
\hline 9 & Upah bongkaran & 3 & $\mathrm{Oh}$ & 1.45 & Rp. $40,000.00$ & $\mathrm{Rp} \quad 174,000.00$ \\
\hline & \multicolumn{5}{|c|}{ Total Biaya } & Rp5,303,552.50 \\
\hline
\end{tabular}

b.Pemasangan bekesting dengan scaffolding (perancah besi).

Pekerjaan pembuatan bekesting ini ditunjang oleh pekerjaan Scafolding. Analisis biaya pekerjaan ini ditunjukkan pada Tabel 2 di bawah.

Tabel 2. Analisis Biaya Pekerjaan Stage $2(\mathrm{n}=2)$ kegiatan pemasangan bekesting dengan scafolding

\begin{tabular}{|c|l|c|c|c|cc|c|}
\hline No & Item Pekerjaan & Volume & Satuan & Koefisien & \multicolumn{2}{|c|}{ Harga Satuan } & Jumlah \\
\hline 1 & Sewa scafolding & 130.8 & $\mathrm{~m} 2$ & 12 & $\mathrm{Rp}$ & $3,850.00$ & $\mathrm{Rp} 6,042,960.00$ \\
\hline 2 & Upah pasang & 130.8 & $\mathrm{~m} 2$ & 1.85 & $\mathrm{Rp}$ & $1,300.00$ & $\mathrm{Rp} 314,574.00$ \\
\hline 3 & Upah bongkaran & 130.8 & $\mathrm{~m} 2$ & 1.25 & $\mathrm{Rp}$ & 900.00 & $\mathrm{Rp} 147,150.00$ \\
\hline 4 & $\begin{array}{l}\text { Kayu kasau } \\
\text { 4cmx6cmx4m }\end{array}$ & 0.186 & $\mathrm{~m} 3$ & & $\mathrm{Rp} 4,250,000.00$ & $\mathrm{Rp} \mathrm{790,500.00}$ \\
\hline & \multicolumn{3}{|c|}{ Total Biaya } & & $\mathrm{Rp7,295,184.00}$ \\
\hline
\end{tabular}

Dua pekerjaan di atas dapat dipilih, namun pekerjaan pembuatan bekesting untuk dua teknik di atas memiliki kesamaan dalam analisis biayanya. Pekerjaan Bekesting yang dilakukan ditunjukkan dalam analisis biaya sebagaimana Tabel 3 di bawah.

Tabel 3. Analisis Biaya Pekerjaan Pembuatan Bekesting

\begin{tabular}{|c|c|c|c|c|c|c|}
\hline No & Item Pekerjaan & Volume & Satuan & Koefisien & Harga Satuan & Jumlah \\
\hline 1 & $\begin{array}{l}\text { Papan kayu } \\
2 \mathrm{~cm} \times 20 \mathrm{~cm} \times 4 \mathrm{~m}\end{array}$ & 175.3 & $\mathrm{bh}$ & & $\mathrm{Rp} \quad 4,000.00$ & Rp 701,200.00 \\
\hline 2 & $\begin{array}{l}\text { Kayu meranti reng } \\
2 \mathrm{~cm} \times 3 \mathrm{~cm} \times 4 \mathrm{~m}\end{array}$ & 0.147 & $\mathrm{~m} 3$ & & Rp3,505,000.00 & Rp $515,235.00$ \\
\hline 3 & $\begin{array}{l}\text { Kayu kasau } \\
4 \mathrm{~cm} \times 6 \mathrm{~cm} \times 4 \mathrm{~m}\end{array}$ & 0.285 & $\mathrm{~m} 3$ & & Rp4,250,000.00 & Rp1,211,250.00 \\
\hline 4 & Paku 7,5 cm & 12.5 & $\mathrm{~kg}$ & & $12,500.00$ & Rp $156,250.00$ \\
\hline 5 & Paku $4 \mathrm{~cm}$ & 10 & $\mathrm{~kg}$ & & $9,750.00$ & $\mathrm{Rp} \quad 97,500.00$ \\
\hline 6 & Upah Mandor & 1 & $\mathrm{Oh}$ & 2.5025 & $65,000.00$ & $\begin{array}{ll}\mathrm{Rp} & 162,662.50 \\
\end{array}$ \\
\hline 7 & Upah tukang & 2 & $\mathrm{Oh}$ & 3.85 & Rp $55,000.00$ & Rp $423,500.00$ \\
\hline 8 & Upah pekerja & 5 & $\mathrm{Oh}$ & 3.85 & $40,000.00$ & $\mathrm{Rp} \quad 770,000.00$ \\
\hline 9 & Upah bongkaran & 3 & $\mathrm{Oh}$ & 1.71 & $40,000.00$ & Rp $205,200.00$ \\
\hline & \multicolumn{5}{|c|}{ Total Biaya } & $\mathrm{Rp} 4,242,797.50$ \\
\hline
\end{tabular}

Dari analisis biaya yang dilakukan dapat dibuat tabel besar biaya dan durasi pelaksanaan pembuatan bekesting dengan perbandingan dua metode di atas, sebagai berikut :

Tabel 4. Perbandingan Analisis Biaya dan Waktu Pekerjaan Pembuatan Bekesting

\begin{tabular}{|l|l|l|}
\hline & Pekerjaan bekesting + Perancah bamboo & Pekerjaan bekesting + Scafolding \\
\hline $\begin{array}{l}\text { Total } \\
\text { biaya }\end{array}$ & Rp.4.242.797,50 + Rp.5,303,552.50 $=\mathrm{Rp}$. & Rp. $4.242 .797,50+\mathrm{Rp} .7,295,184.00=$ \\
\hline Durasi & $5.546 .350,00$ & Rp. $11.537 .981,50$ \\
\hline
\end{tabular}


3. Stage $1(n=1)$, merupakan Tahap Pengecoran Beton $(19,62 \mathrm{~m} 3)$

Tahap ini merupakan tahap pengecoran beton, yang terdiri dari 3 option pilihan, meliputi:

\section{a. Pengecoran dengan cara manual}

Pekerjaan pengecoran ini dilakukan dengan cara manual (murni tenaga manusia). Analisis biaya pekerjaan ini ditunjukkan pada Tabel 5 di bawah.

Tabel 5. Analisis Biaya Pekerjaan Stage $1(n=1)$ kegiatan pengecoran beton cara manual

\begin{tabular}{|c|c|c|c|c|c|c|}
\hline No & Item Pekerjaan & Volume & Satuan & Koefisien & Harga Satuan & Jumlah \\
\hline 1 & Semen & 6278.4 & $\mathrm{~kg}$ & & $\mathrm{Rp} 1,200.00$ & Rp 7,534,080.00 \\
\hline 2 & Pasir & 10.5948 & $\mathrm{~m} 3$ & & Rp123,500.00 & Rp $1,308,457.80$ \\
\hline 3 & Kerikil & 16.0884 & $\mathrm{~m} 3$ & & Rp 61,900.00 & $995,871.96$ \\
\hline 4 & Mandor & 1 & $\mathrm{Oh}$ & 2.4336 & Rp $65,000.00$ & $158,184.00$ \\
\hline 5 & Tukang & 2 & $\mathrm{Oh}$ & 5.07 & Rp $55,000.00$ & Rp $\quad 557,700.00$ \\
\hline 6 & Pekerja & 5 & $\mathrm{Oh}$ & 5.07 & Rp $40,000.00$ & Rp $1,014,000.00$ \\
\hline & \multicolumn{5}{|c|}{ Total Biaya } & Rp11,568,293.76 \\
\hline
\end{tabular}

\section{b. Pengecoran dengan menggunakan small concrete mixer}

Pekerjaan pengecoran ini dilakukan dengan menggunakan small concrete mixer. Analisis biaya pekerjaan ini ditunjukkan pada Tabel 6 di bawah.

Tabel 6. Analisis Biaya Pekerjaan Stage $1(n=1)$ kegiatan pengecoran beton dengan menggunakan small concrete mixer

\begin{tabular}{|c|c|c|c|c|c|c|}
\hline No & Item Pekerjaan & Volume & Satuan & Koefisien & Harga Satuan & Jumlah \\
\hline 1 & $\begin{array}{l}\text { Sewa peralatan } \\
\text { concrete mixer }\end{array}$ & 3.72 & $\mathrm{Oh}$ & & Rp 270,000.00 & Rp $1,004,400.00$ \\
\hline 2 & Semen & 6278.4 & $\mathrm{~kg}$ & & $1,200.00$ & Rp 7,534,080.00 \\
\hline 3 & Pasir & 10.5948 & $\mathrm{~m} 3$ & & Rp $123,500.00$ & Rp 1,308,457.80 \\
\hline 4 & Kerikil & 16.0884 & $\mathrm{~m} 3$ & & Rp $61,900.00$ & Rp $\quad 995,871.96$ \\
\hline 5 & Mandor & 1 & $\mathrm{Oh}$ & 1.7376 & Rp $65,000.00$ & $112,944.00$ \\
\hline 6 & Tukang & 2 & $\mathrm{Oh}$ & 3.62 & Rp $55,000.00$ & $398,200.00$ \\
\hline 7 & Pekerja & 5 & $\mathrm{Oh}$ & 3.62 & Rp $40,000.00$ & $724,000.00$ \\
\hline 8 & Bahan bakar & 26.04 & ltr & & $4,500.00$ & Rp $\quad 117,180.00$ \\
\hline & \multicolumn{5}{|c|}{ Total Biaya } & Rp12,195,133.76 \\
\hline
\end{tabular}

\section{c. Pengecoran dengan dengan ready mix dan concrete pump}

Pekerjaan pengecoran ini dilakukan dengan ready mix dan concrete pump. Analisis biaya pekerjaan ini ditunjukkan pada Tabel 7 di bawah.

Tabel 7. Analisis Biaya Pekerjaan Stage $1(\mathrm{n}=1)$ kegiatan pengecoran beton dengan menggunakan ready mix dan concrete pump

\begin{tabular}{|c|c|c|c|c|c|c|}
\hline & Item Pekerjaan & Volume & Satuan & Koefisien & Harga Satuan & Jumlah \\
\hline 1 & Harga beton segar & 19.62 & m3 & & Rp $500,000.00$ & Rp 9,810,000.00 \\
\hline 2 & $\begin{array}{l}\text { Sewa concrete } \\
\text { pump }\end{array}$ & 2.5 & jam & & Rp1,250,000.00 & Rp 3,125,000.00 \\
\hline 3 & Mandor & 1 & Oh & 0.232143 & $\mathrm{Rp} \quad 65,000.00$ & $15,089.29$ \\
\hline 4 & Tukang & 1 & $\mathrm{Oh}$ & 0.357143 & $\mathrm{Rp} \quad 55,000.00$ & $19,642.86$ \\
\hline 5 & Pekerja & 2 & $\mathrm{Oh}$ & 0.357143 & $40,000.00$ & $28,571.43$ \\
\hline & \multicolumn{5}{|c|}{ Total Biaya } & Rp12,998,303.57 \\
\hline
\end{tabular}

Tabel 8. Analisis Biaya Pekerjaan Pembesian

\begin{tabular}{|c|c|c|c|c|c|c|}
\hline & Item Pekerjaan & Volume & Satuan & Koefisien & Harga Satuan & Jumlah \\
\hline 1 & Besi SA $\emptyset=12$ & 106.875 & M & & Rp 77,875.00 & Rp 8,322,890.63 \\
\hline 2 & Besi SA $\emptyset=10$ & 42.375 & M & & Rp $67,750.00$ & Rp 2,870,906.25 \\
\hline 3 & Kawat bendrat & 25 & $\mathrm{Kg}$ & & Rp $15,100.00$ & Rp $\quad 377,500.00$ \\
\hline 4 & Upah Mandor & 1 & $\mathrm{Oh}$ & 2.0605 & Rp $65,000.00$ & Rp $133,932.50$ \\
\hline 5 & Upah tukang & 2 & $\mathrm{Oh}$ & 3.17 & Rp $55,000.00$ & Rp $348,700.00$ \\
\hline 6 & Upah pekerja & 4 & $\mathrm{Oh}$ & 3.17 & $\mathrm{Rp} \quad 40,000.00$ & Rp $\quad 507,200.00$ \\
\hline & \multicolumn{5}{|c|}{ Total Biaya } & Rp12,561,129.38 \\
\hline
\end{tabular}


Selain tahapan teknik pengecoran di atas, pekerjaan pengecoran didahului dengan pekerjaan pembesian. Dimana pekerjaan pembesian ini juga tercakup untuk setiap teknik pelaksanaan dari ketiga teknik tersebut di atas (Tabel 8)

Dari analisis biaya yang dilakukan dapat dibuat tabel besar biaya dan durasi pelaksanaan pengecoran dengan perbandingan tiga metode di atas, sebagai berikut :

Tabel 9. Perbandingan Analisis Biaya dan Waktu Pekerjaan Pengecoran

\begin{tabular}{|l|l|l|l|}
\hline & $\begin{array}{l}\text { Pekerjaan pembesian } \\
\text { pengecoran manual }\end{array}$ & $\begin{array}{l}\text { Pekerjaan pembesian + } \\
\text { Pengecoran dengan small } \\
\text { concrete mixer }\end{array}$ & $\begin{array}{l}\text { Pekerjaan pembesian }+ \\
\text { Pengecoran } \\
\text { ready mix }\end{array}$ \\
\hline Total & $\mathrm{Rp} .12 .561 .129,38+$ & $\mathrm{Rp} .12 .561 .129,38+$ & $\mathrm{Rp} .12 .561 .129,38+$ \\
biaya & $\mathrm{Rp} .11 .568 .293,76=$ & $\mathrm{Rp} 12.195 .133,76=$ & $\mathrm{Rp} .12 .998 .303,57=$ \\
& $\mathrm{Rp} .24 .129 .423,14$ & $\mathrm{Rp} .24 .756 .263,14$ & $\mathrm{Rp} .25 .559 .432,95$ \\
\hline Durasi & $3,17 \mathrm{hr}+5,87 \mathrm{hr}=$ & $3,17 \mathrm{hr}+4,12 \mathrm{hr}=$ & $3,17 \mathrm{hr}+0,357 \mathrm{hr}=$ \\
& $9,04 \mathrm{hr}$ & $7,29 \mathrm{hr}$ & $3,527 \mathrm{hr}$ \\
\hline
\end{tabular}

4. Stage $0(n=0)$, merupakan Tahap Pengerasan Beton (curing beton).

Pada tahap ini pekerjaan pengecoran plat selesai, dan menunggu masa pengerasan beton (curing beton).

\section{PEMODELAN DAN OPTIMASI DENGAN PROGRAM DINAMIK}

\section{Pemodelan Program Dinamik}

Dari beberapa langkah analisis biaya dan waktu pelaksanaan proyek di atas, maka dapat dibuat model jaringan langkah atau tahapan pekerjaan. Jaringan tersebut dibentuk dengan 4 stages $(0,1,2$, dan 3$)$ dan 7 states, dengan state $G$ pada stage 0 , state $D, E$,dan $F$ pada stage 1 , state $B$ dan $C$ pada stage 2, dan state A pada stage 3. Penjelasan model jaringan tersebut ditunjukkan pada Gambar 5 di bawah.

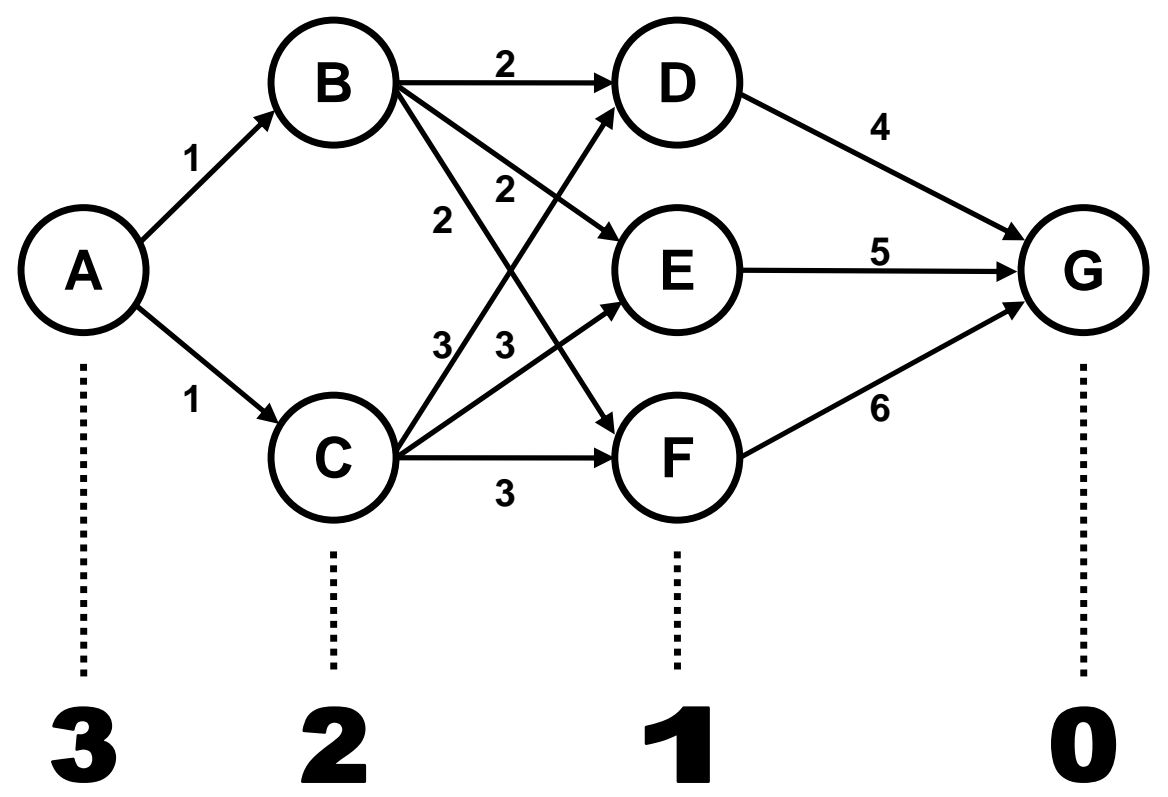

Gambar 5. Bagan Jaringan Tahapan Pelaksanaan Pengecoran Plat Lantai Greenhouse

\section{Keterangan:}

A : Tahap Persiapan Pengecoran

B: Tahap pemasangan bekesting dengan perancah bamboo

C: Tahap pemasangan bekesting dengan scaffolding (perancah besi)

D : Pengecoran secara manual

E : Pengecoran dengan small concrete mixer

F : Pengeceron dengan ready mix dan concrete pump

G : Pengecoran selesai / curing beton
Dari hasil analisa biaya dikaitkan dengan bagan jaringan pada Gambar 5, didapatkan penjelasan sebagai berikut

1 = biaya Rp. 500.000,- dan durasi 1 hari

2 = biaya Rp. 9.546.350,- dan durasi 10,26 hari

3 = biaya $\operatorname{Rp} 11.537981,50$ dan durasi 8,66 hari

4 = biaya Rp. 24.129.423,14 dan durasi 9,04 hari 
5 = biaya Rp. 24.756.263,14 dan durasi 7,29 hari

6 = biaya Rp 25.559.432,95 dan durasi 3,527 hari

Biaya dan lamanya waktu antara dua metode disebut dengan $\mathrm{J}_{\mathrm{mn}}$ (biaya) dan $\mathrm{P}_{\mathrm{mn}}$ (waktu), dimana $\mathrm{m}$ adalah tahap awal dan $\mathrm{n}$ tahap berikutnya. Biaya dari A ke B dengan besar $\mathrm{J}_{\mathrm{AB}}$ $=\mathrm{Rp} 500.000,-$ dan waktu proyek $\mathrm{P}_{\mathrm{AB}}=1$ hari. Adapun besar biaya dan lama waktu dari bagan tersebut dijelaskan pada Tabel 10 - 11 di bawah sebagai berikut:

Tabel 10. Biaya Proyek

\begin{tabular}{|c|c|c|c|}
\hline $\mathrm{J}_{\mathrm{AB}}=$ Rp.500.000,- & $\mathrm{J}_{\mathrm{BD}}=\mathrm{Rp} .9 .546 .350,-$ & $\mathrm{J}_{\mathrm{CE}}=\mathrm{Rp} \cdot 11.537 .981,5$ & $\mathrm{~J}_{\mathrm{DG}}=\mathrm{Rp} \cdot 24 \cdot 129.423,14$ \\
\hline $\mathrm{J}_{A C}=$ Rp.500.000,- & $\mathrm{J}_{\mathrm{BE}}=$ Rp.9.546.350,- & $\mathrm{J}_{\mathrm{CF}}=\mathrm{Rp} .11 .537 .981,5$ & $\mathrm{~J}_{\mathrm{EG}}=\mathrm{Rp} \cdot 24.756263,14$ \\
\hline & $\mathrm{J}_{\mathrm{BF}}=$ Rp.9.546.350,- & $\mathrm{J}_{\mathrm{CD}}=\mathrm{Rp} .11 .537 .981,5$ & $\mathrm{~J}_{\mathrm{FG}}=\mathrm{Rp} .25 .559 .432,95$ \\
\hline
\end{tabular}

Tabel 11. Lama (waktu) Proyek

\begin{tabular}{|l|l|l|l|}
\hline $\mathrm{P}_{\mathrm{AB}}=2$ hari & $\mathrm{P}_{\mathrm{BD}}=10,26$ hari & $\mathrm{P}_{\mathrm{CE}}=8,66$ hari & $\mathrm{P}_{\mathrm{DG}}=9,04$ hari \\
\hline $\mathrm{P}_{\mathrm{AC}}=2$ hari & $\mathrm{P}_{\mathrm{BE}}=10,26$ hari & $\mathrm{P}_{\mathrm{CF}}=8,66$ hari & $\mathrm{P}_{\mathrm{EG}}=7,29$ hari \\
\hline & $\mathrm{P}_{\mathrm{BF}}=10,26$ hari & $\mathrm{P}_{\mathrm{CD}}=8,66$ hari & $\mathrm{P}_{\mathrm{FG}}=3,57$ hari \\
\hline
\end{tabular}

\section{Proses Optimasi dengan Program Dinamik}

Proses optimasi ini dilakukan dengan metode induksi mundur, yang dimulai dengan tahapan akhir atau tujuan, kemudian diurutkan secara mundur sampai ke awal permasalahan. Proses optimasi yang dicari adalah meminimumkan biaya dan waktu dilakukan pada setiap stage, sebagai berikut :

\section{a. Stage 0 (tahap pengerasan beton/} curing beton)

Dengan fungsi $(n)=0$, didapat $f_{0}(G)=0$; $\mathrm{K}_{0}=$ stop. Tahap ini merupakan akhir dari proses pelaksanaan pengecoran plat lantai. Jadi pada stage 0 ini pekerjaan berhenti.

\section{b. Stage 1 (tahap pengecoran beton)}

Tahap stage 1 difungsikan sebagai $\mathrm{n}=1$, $\mathrm{f}_{1}(\mathrm{~S})=\mathrm{J}_{\mathrm{n}-1}+\mathrm{f}_{0}(\mathrm{x})$ dan $\mathrm{g}_{1}(\mathrm{~S})=\mathrm{J}_{\mathrm{n}-1}+\mathrm{g}_{0}(\mathrm{x})$. Tahap ini adalah pengecoran beton dengan urutan langkah metode sebagai berikut,

- Untuk tahap DG

$$
f_{1}(D)=\left\{J_{D G}+f_{0}(G)\right\}=R p \cdot 24 \cdot 129 \cdot 423,14+0
$$$$
=\text { Rp. } 24.129 .423,14, K_{1}(D)=\text { go to } G
$$

$$
\begin{aligned}
\mathrm{g}_{1}(\mathrm{D}) & =\left\{\mathrm{P}_{\mathrm{DG}}+\mathrm{g}_{0}(\mathrm{G})\right\}=9,04 \text { hari }+0 \\
& =9,04 \text { hari, } \mathrm{K}_{1}(\mathrm{D})=\text { go to } \mathrm{G}
\end{aligned}
$$

\section{- Untuk tahap EG}

$$
\begin{aligned}
\mathrm{f}_{1}(\mathrm{E}) & =\left\{\mathrm{JEG}_{\mathrm{EG}}+\mathrm{f}_{0}(\mathrm{G})\right\}=\text { Rp.24.756.263,14 + } 0 \\
& =\mathrm{Rp} .24 .756 .263,14, \mathrm{~K}_{1}(\mathrm{E})=\text { go to } \mathrm{G} \\
\mathrm{g}_{1}(\mathrm{E}) & =\left\{\mathrm{P}_{\mathrm{EG}}+\mathrm{g}_{0}(\mathrm{G})\right\}=\text { Rp.7,29 hari }+0 \\
& =7,29 \text { hari, } \mathrm{K}_{1}(\mathrm{G})=\text { go to } \mathrm{G} \\
\text { - Untuk tahap FG } & \\
\mathrm{f}_{1}(\mathrm{~F}) & =\left\{\mathrm{J}_{\mathrm{FG}}+\mathrm{f}_{0}(\mathrm{G})\right\}=\text { Rp. } 25.559 .432,95+0 \\
& =\text { Rp. } 24.756 .263,14, \mathrm{~K}_{1}(\mathrm{~F})=\text { go to } \mathrm{G} \\
\mathrm{g}_{1}(\mathrm{~F}) & =\left\{\mathrm{P}_{\mathrm{FG}}+\mathrm{g}_{0}(\mathrm{G})\right\}=\text { Rp.3,527 hari }+0 \\
& =3,527 \text { hari, } \mathrm{K}_{1}(\mathrm{G})=\text { go to } \mathrm{G}
\end{aligned}
$$

\section{- Untuk tahap FG}

Besar biaya yang termurah pada $\mathrm{f}_{1}(\mathrm{D})=\mathrm{Rp}$.

\begin{tabular}{|c|c|c|c|}
\hline State $S$ & Keputusan $=\mathrm{K}$ & $K_{1}(\mathbf{S})$ & $\mathbf{f}_{\mathbf{1}}(\mathbf{S})$ \\
\hline $\mathrm{D}$ & $\begin{array}{l}\text { Biaya = Rp.24.129.423,14+ 0 = Rp.24.129.423,14 } \\
\text { Waktu = Rp.3,527 hari + 0 = 3,527 hari }\end{array}$ & G & $\begin{array}{l}\text { Rp.24.129.423,14 } \\
\text { 3,527 hari }\end{array}$ \\
\hline $\mathrm{E}$ & $\begin{array}{l}\text { Biaya }=\text { Rp. } 24.756 \cdot 263,14+0=\text { Rp. } 24 \cdot 756 \cdot 263,14 \\
\text { Waktu }=\text { Rp.7,29 hari }+0=7,29 \text { hari }\end{array}$ & G & $\begin{array}{l}\text { Rp. } 24.756 .263,14 \\
7,29 \text { hari }\end{array}$ \\
\hline $\mathrm{F}$ & $\begin{array}{l}\text { Biaya = Rp.25.559.432,95 + 0 = Rp. } 24.756 .263,14 \\
\text { Waktu = Rp.3,527 hari }+0=3,527 \text { hari }\end{array}$ & G & $\begin{array}{l}\text { Rp. } 24.756 .263,14 \\
3,527 \text { hari }\end{array}$ \\
\hline
\end{tabular}
24.129.423,14, dan lama waktu yang paling singkat adalah $\mathrm{g}_{1}(\mathrm{~F})$ dengan 3,527 hari. Keputusan pada biaya termurah dengan cara pengecoran secara manual melibatkan tenaga manusia. Sedangkan apabila kita memilih waktu yang tercepat dan paling singkat maka kita gunakan tahap $\mathrm{F}$ menuju $\mathrm{G}$ dengan menggunakan ready mix. Kondisi pada stage 1 ini dapat ditabelkan seperti di bawah ini:

Tabel 12. Stage 1

\section{c. Stage 2 (tahap Pemasangan dan Pembuatan Bekesting)}

Stage 2 dengan fungsi $n=2, f_{2}(S)=J_{n-1}+$ $\mathrm{f}_{0}(\mathrm{x})$ dan $\mathrm{g}_{2}(\mathrm{~S})=\mathrm{J}_{\mathrm{n}-1}+\mathrm{g}_{0}(\mathrm{x})$. Pada tahap ini dilakukan pemasangan dan pembuatan bekesting, dengan langkah-langkah berikut :

- Untuk tahap BD

$$
\begin{aligned}
\mathrm{f}_{2}(\mathrm{~B}) & =\left\{J_{B D}+\mathrm{f}_{1}(\mathrm{D})\right\} \\
& =\text { Rp. } 9.546 .350+\text { Rp.24.129.423,14 } \\
& =\text { Rp.33.675.773,14, } \mathrm{K}_{2}(\mathrm{~B})=\text { go to } \mathrm{D}
\end{aligned}
$$

$$
\begin{aligned}
g_{2}(B) & =\left\{P_{B D}+g_{1}(D)\right\} \\
& =10,26 \text { hari }+9,04 \text { hari }=19,30 \text { hari, } \\
K_{2}(B) & =\text { go to } D
\end{aligned}
$$

- Untuk tahap BE

$$
\begin{aligned}
\mathrm{f}_{2}(\mathrm{~B}) & =\left\{\mathrm{J}_{\mathrm{BE}}+\mathrm{f}_{1}(\mathrm{E})\right\} \\
& =\operatorname{Rp} \cdot 9 \cdot 546.350+\mathrm{Rp} \cdot 24.756 .263,14 \\
& =\text { Rp.34.302.613,14, } \mathrm{K}_{2}(\mathrm{~B})=\text { go to } \mathrm{E} \\
\mathrm{g}_{2}(\mathrm{~B}) & =\left\{\mathrm{P}_{\mathrm{BE}}+\mathrm{g}_{1}(\mathrm{E})\right\} \\
& =10,26 \text { hari }+7,29 \text { hari }=18,05 \text { hari, } \\
\mathrm{K}_{2}(\mathrm{~B}) & =\text { go to } \mathrm{E}
\end{aligned}
$$


- Untuk tahap BF

$$
\begin{aligned}
\mathrm{f}_{2}(\mathrm{~B}) & =\left\{\mathrm{J}_{\mathrm{BF}}+\mathrm{f}_{1}(\mathrm{~F})\right\} \\
& =\text { Rp. } 9.546 .350+\text { Rp.25.559.432,95 } \\
& =\text { Rp.35.105.782,95, } \mathrm{K}_{2}(\mathrm{~B})=\text { go to } \mathrm{F} \\
\mathrm{g}_{2}(\mathrm{~B}) & =\left\{\mathrm{P}_{\mathrm{BF}}+\mathrm{g}_{1}(\mathrm{~F})\right\} \\
& =10,26 \text { hari }+3,527 \text { hari } \\
& =13,787 \text { hari, } \\
\mathrm{K}_{2}(\mathrm{~B}) & =\text { go toF }
\end{aligned}
$$

- Untuk tahap CD

$$
\begin{aligned}
\mathrm{f}_{2}(\mathrm{C}) & =\left\{\mathrm{J}_{\mathrm{CD}}+\mathrm{f}_{1}(\mathrm{D})\right\} \\
& =\mathrm{Rp} \cdot 11.537 .981,5+\mathrm{Rp} .24 .129 .423,14 \\
& =\text { Rp.35.667.404,64, } \mathrm{K}_{2}(\mathrm{C})=\text { go to } \mathrm{D} \\
\mathrm{g}_{2}(\mathrm{C}) & =\left\{\mathrm{P}_{\mathrm{CD}}+\mathrm{g}_{1}(\mathrm{D})\right\} \\
& =8,66 \text { hari }+9,04 \text { hari }=17,70 \text { hari, } \\
\mathrm{K}_{2}(\mathrm{C}) & =\text { go to } \mathrm{D}
\end{aligned}
$$

- Untuk tahap CE

$$
\begin{aligned}
\mathrm{f}_{2}(\mathrm{C}) & =\left\{\mathrm{JCE}_{\mathrm{CE}}+\mathrm{f}_{1}(\mathrm{E})\right\} \\
& =\mathrm{Rp} \cdot 11.537 .981,5+\mathrm{Rp} .24 .756 .263,14 \\
& =\mathrm{Rp} \cdot 36.294 .244,64, \mathrm{~K}_{2}(\mathrm{C})=\text { go to } \mathrm{E} \\
\mathrm{g}_{2}(\mathrm{C}) & =\left\{\mathrm{P}_{\mathrm{CE}}+\mathrm{g}_{1}(\mathrm{E})\right\} \\
& =8,66 \text { hari }+7,29 \text { hari }=15,95 \text { hari, }
\end{aligned}
$$

\begin{tabular}{|c|c|c|c|c|c|}
\hline \multirow{2}{*}{$\begin{array}{c}\text { State } \\
\text { S }\end{array}$} & \multicolumn{3}{|c|}{ Keputusan } & \multirow{2}{*}{$\mathbf{K}_{1}(\mathbf{S})$} & \multirow{2}{*}{$\mathbf{f}_{1}(\mathbf{S})$} \\
\hline & $x=D$ & $\mathbf{x}=\mathbf{E}$ & $x=F$ & & \\
\hline $\mathrm{B}$ & $\begin{array}{l}\text { Biaya }= \\
\text { Rp.9.546.350 + } \\
\text { Rp.24.129.423,14 } \\
=\text { Rp.33.675.773,14 } \\
\text { Waktu = } \\
\text { 10,26 hari + 9,04 } \\
\text { hari = 19,30 hari }\end{array}$ & $\begin{array}{l}\text { Biaya }= \\
\text { Rp.9.546.350 + } \\
\text { Rp.24.756.263,14 = } \\
\text { Rp.34.302.613,14 } \\
\text { Waktu }= \\
\text { 10,26 hari + 7,29 } \\
\text { hari }=18,05 \text { hari, }\end{array}$ & $\begin{array}{l}\text { Biaya }= \\
\text { Rp.9.546.350 + } \\
\text { Rp.25.559.432,95 = } \\
\text { Rp.35.105.782,95 } \\
\text { Waktu }= \\
\text { 10,26 hari + 3,527 } \\
\text { hari = 13,787 hari }\end{array}$ & $\begin{array}{l}\text { Biaya: } \\
\text { D } \\
\text { Waktu: } \\
\text { F }\end{array}$ & $\begin{array}{l}\text { Rp.33.675.773,14, } \\
\text { 13,787 hari }\end{array}$ \\
\hline $\mathrm{C}$ & $\begin{array}{l}\text { Biaya }= \\
\text { Rp.11.537.981,5 + } \\
\text { Rp.24.129.423,14 = } \\
\text { Rp.35.667.404,64 } \\
\text { Waktu = } \\
\text { 8,66 hari + 9,04 hari } \\
=17,70 \text { hari, }\end{array}$ & $\begin{array}{l}\text { Biaya }= \\
\text { Rp.11.537.981,5 + } \\
\text { Rp.24.756.263,14 = } \\
\text { Rp.36.294.244,64 } \\
\text { Waktu }= \\
8,66 \text { hari }+7,29 \\
\text { hari }=15,95 \text { hari }\end{array}$ & $\begin{array}{l}\text { Biaya }= \\
\text { Rp.11.537.981,5 + } \\
\text { Rp.25.559.432,95 = } \\
\text { Rp.37.097.414,45, } \\
\text { Waktu = } \\
\text { 8,66 hari + 3,527 } \\
\text { hari = 12,187 hari, }\end{array}$ & $\begin{array}{l}\text { Biaya : } \\
\text { D } \\
\text { Waktu: } \\
\text { F }\end{array}$ & $\begin{array}{l}\text { Rp.35.667.404,64 } \\
12,187 \text { hari }\end{array}$ \\
\hline
\end{tabular}

$\mathrm{K}_{2}(\mathrm{C})=$ go to $\mathrm{E}$

- Untuk tahap CF

$$
\begin{aligned}
\mathrm{f}_{2}(\mathrm{C}) & =\left\{\mathrm{J}_{\mathrm{CF}}+\mathrm{f}_{1}(\mathrm{~F})\right\} \\
& =\text { Rp.11.537.981,5+Rp.25.559.432,95 } \\
& =\text { Rp.37.097.414,45, } \mathrm{K}_{2}(\mathrm{C})=\text { go to } \mathrm{F} \\
\mathrm{g}_{2}(\mathrm{C}) & =\left\{\mathrm{P}_{\mathrm{CF}}+\mathrm{g}_{1}(\mathrm{~F})\right\} \\
& =8,66 \text { hari }+3,527 \text { hari } \\
& =12,187 \text { hari, } \\
\mathrm{K}_{2}(\mathrm{C}) & =\text { go to } \mathrm{F}
\end{aligned}
$$

Besar biaya yang termurah pada $\mathrm{f}_{2}(\mathrm{~B})=$ Rp.33.675.773,14, dan lama waktu yang paling singkat adalah $\mathrm{g}_{2}(\mathrm{C})$ sebesar 12,187 hari. Keputusan yang diambil untuk biaya termurah dengan cara pembuatan perancah dari bambu. Sedangkan apabila kita memilih waktu yang tercepat dan paling singkat adalah dengan menggunakan Scafolding. Biaya termurah dan waktu paling singkat yang ditempuh pada stage 2 ini dapat ditabelkan sebagai berikut :

Tabel 13. Stage 2

\section{d. Stage 3 (tahap persiapan)}

Stage ini difungsikan dengan, $n=3, f_{3}(S)=$ $\mathrm{J}_{\mathrm{n}-1}+\mathrm{f}_{2}(\mathrm{x})$ dan $\mathrm{g}_{3}(\mathrm{~S})=\mathrm{J}_{\mathrm{n}-1}+\mathrm{g}_{2}(\mathrm{x})$. langkah pengerjaan pada stage 3 ini adalah sebagai berikut,

- Untuk tahap AB

$$
\begin{aligned}
\mathrm{f}_{3}(\mathrm{~A}) & =\left\{\mathrm{J}_{A B}+\mathrm{f}_{2}(\mathrm{~B})\right\} \\
& =\text { Rp.500.000 }+ \text { Rp.33.675.773,14 } \\
& =\text { Rp.34.175.773,14, } \mathrm{K}_{3}(\mathrm{~A})=\text { go to } \mathrm{B} \\
\mathrm{g}_{3}(\mathrm{~A}) & =\left\{\mathrm{P}_{A B}+\mathrm{g}_{2}(\mathrm{~B})\right\} \\
& =1 \text { hari }+13,787 \text { hari }=14.787 \text { hari, } \\
\mathrm{K}_{3}(\mathrm{~A}) & =\text { go to } \mathrm{B}
\end{aligned}
$$

- Tahap AC

$$
\begin{aligned}
\mathrm{f}_{3}(\mathrm{~A}) & =\left\{J_{A C}+\mathrm{f}_{2}(\mathrm{C})\right\} \\
& =\mathrm{Rp} .500 .000+\mathrm{Rp} .35 .667 .404,64 \\
& =\mathrm{Rp} .36 .167 .404,64, \mathrm{~K}_{3}(\mathrm{~A})=\text { go to } \mathrm{C}
\end{aligned}
$$

$$
\begin{aligned}
\mathrm{g}_{3}(\mathrm{~A})= & \left\{\mathrm{P}_{\mathrm{AC}}+\mathrm{g}_{2}(\mathrm{C})\right\} \\
& =1 \text { hari }+12,187 \text { hari }=13.187 \text { hari, } \\
\mathrm{K}_{3}(\mathrm{~A}) & =\text { go to } \mathrm{C}
\end{aligned}
$$

Besar biaya yang termurah pada $\mathrm{f}_{3}(\mathrm{~A})=$ Rp.34.175.773,14, dan lama waktu yang paling singkat adalah $\mathrm{g}_{2}(\mathrm{C})$ sebesar 13,187 hari. Keputusan untuk biaya termurah kita pakai tahap A menuju B. Sedangkan apabila kita memilih waktu yang tercepat maka kita gunakan tahap A menuju C. Kondisi pada stage 2 ini dapat ditabelkan seperti di bawah ini : 
Tabel 14. Stage 3

\begin{tabular}{|c|c|c|c|c|}
\hline \multirow{2}{*}{$\begin{array}{c}\text { State } \\
\text { S }\end{array}$} & \multicolumn{2}{|c|}{ Keputusan } & \multirow{2}{*}{$\mathbf{K}_{3}(\mathbf{S})$} & \multirow{2}{*}{$f_{3}(S)$} \\
\hline & $\mathbf{x}=\mathbf{B}$ & $\mathrm{x}=\mathrm{C}$ & & \\
\hline $\mathrm{A}$ & $\begin{array}{l}\text { Biaya }= \\
\text { Rp.500.000 + Rp.33.675.773,14 } \\
=\text { Rp. } 34.175 .773,14 \\
\text { Waktu }= \\
1 \text { hari }+13,787 \text { hari }= \\
14.787 \text { hari }\end{array}$ & $\begin{array}{l}\text { Biaya }= \\
\text { Rp.500.000 + Rp.35.667.404,64 } \\
=\text { Rp.36.167.404,64 } \\
\text { Waktu = } \\
1 \text { hari }+12,187 \text { hari }= \\
\text { 13.187 hari }\end{array}$ & $\begin{array}{l}\text { Biaya: } \\
\text { E } \\
\text { Waktu: } \\
\text { C }\end{array}$ & $\begin{array}{l}\text { Rp.34.175.773,14 } \\
13,187 \text { hari }\end{array}$ \\
\hline
\end{tabular}

\section{e. Perbandingan Hasil Analisis Untuk} Biaya dan Waktu Proyek

Dari proses perhitungan secara manual seperti sebelumnya di dapatkan metode pelaksanaan yang optimum sebagai berikut,

1. Biaya paling minimum didapatkan dengan urutan dengan urutan tahapan A-B-D-G dengan biaya Rp.34.175.773,14. Deskripsi tahapan tersebut dimulai : Tahapan persiapan - Pemasangan bekesting + perancah bambu - Pengecoran beton secara manual - Curing beton. Namun dari segi waktu durasi proyek membutuhkan waktu 20,3 hari.

2. Waktu tercepat didapatkan dengan urutan langkah dengan urutan A-C-F-G yang memakan waktu 13,187 hari, dengan penjelasan urutan tahapan pelaksanaan : Tahap Persiapan Pengecoran Pemasangan bekesting dengan scaffolding (perancah besi) - Pengeceron dengan ready mix dan concrete pump - Curing beton. Sementara biaya yang dibutuhkan untuk tahapan ini adalah sebesar Rp. 37.597.414,45.

\section{NETWORK ANALYSIS DENGAN PROGRAM DS WINDOWS 2.0}

Proses ini dilakukan dengan memakai program Bantu DS Win 2.0 untuk melakukan evaluasi dan perbandingan terhadap perhitungan yang dilakukan secara manual dengan program dinamik. Analisis yang dilakukan adalah analisis jaringan (network) yang menghubungkan notenote yang berisi metode pelaksanaan pengecoran. Hasil yang hendak dicapai adalah yang paling minimum. Hasil pengerjaannya adalah berikut ini,

\section{Minimasi Biaya Pelaksanaan Pengecoran Beton}

Proses perhitungan diawali dengan input data setiap cabang yang merupakan jalur network biaya pekerjaan yang terdiri dari 11 cabang sebagaimana pada Tabel 15.

Setelah dibuat jaringan dan diinput data seperti pada Tabel 15, selanjutnya dilakukan running solver yang menghasilkan output perhitungan sebagaimana pada Tabel $16 \mathrm{di}$ bawah.

Tabel 15. Input Data Cabang Network Biaya Pelaksanaan

\begin{tabular}{|l|r|r|r|} 
& Start node & End node & Distance \\
\hline Eranch 1 & 1 & 2 & $500,000$. \\
\hline Eranch 2 & 1 & 3 & $500,000$. \\
\hline Eranch 3 & 2 & 4 & $9,546,350$. \\
\hline Eranch 4 & 2 & 5 & $9,546,350$. \\
\hline Eranch 5 & 2 & 6 & $9,546,350$. \\
\hline Eranch 6 & 3 & 4 & $11,537,980$. \\
\hline Eranch 7 & 3 & 5 & $11,537,980$. \\
\hline Eranch 8 & 3 & 6 & $11,537,980$. \\
\hline Eranch 9 & 4 & 7 & $24,129,420$. \\
\hline Eranch 10 & 5 & 7 & $24,756,260$. \\
\hline Eranch 11 & 6 & 7 & $25,559,430$. \\
\hline
\end{tabular}

Tabel 16. Ouput Running Solver Optimasi Biaya Minimum

\begin{tabular}{l|r|r|r|r|}
\hline Total distance $=3.417578 \mathrm{E}+07$ & Start node & End node & Distance & $\begin{array}{r}\text { Cumulative } \\
\text { Distance }\end{array}$ \\
\hline Branch 1 & 1. & 2. & $500,000$. & $500,000$. \\
\hline Branch 3 & 2. & 4. & $9,546,350$. & $10,046,350$. \\
\hline Branch 9 & 4. & 7. & $24,129,420$. & $34,175,780$.
\end{tabular}


Dari tabel di atas tampak bahwa hasil urutan tahapan pekerjaan pengecoran adalah cabang 1 - 3 - 9 atau kalau menurut Gambar 5, tahap A-B-D-G, dengan besar biaya Rp 34.175.780, Hal ini menunjukkan persamaan dengan hasil perhitungan pemrograman dinamik, hanya terdapat perbedaan pada besar biaya, karena program DS Win 2.0 membaca angka pembulatan terdekat dari data angka yang dimasukkan (input).

\section{Minimasi Waktu Pelaksanaan Pengecoran Beton}

Langkah ini sama dengan minimasi biaya, hanya saja item yang dioptimasi adalah waktu pengerjaan proyek yang terdiri dari 11 cabang network. Input data sebagaimana Tabel 17.

Hasil input pada Tabel 17 di proses melalui solver, sehingga didapatkan hasil running seperti pada Tabel 18 yang merupakan waktu minimum atau yang paling cepat.

Tabel 17. Input Data Cabang Network Waktu Pelaksanaan

\begin{tabular}{|l|r|r|r|}
\hline & Start node & End node & Distance \\
\hline Branch 1 & 1 & 2 & 1. \\
\hline Branch 2 & 1 & 3 & 1. \\
\hline Branch 3 & 2 & 4 & 10.26 \\
\hline Branch 4 & 2 & 5 & 10.26 \\
\hline Branch 5 & 2 & 6 & 10.26 \\
\hline Branch 6 & 3 & 4 & 8.66 \\
\hline Branch 7 & 3 & 5 & 8.66 \\
\hline Branch 8 & 3 & 6 & 8.66 \\
\hline Branch 9 & 4 & 7 & 9.04 \\
\hline Branch 10 & 5 & 7 & 7.29 \\
\hline Branch 11 & 6 & 7 & 3.527 \\
\hline
\end{tabular}

Tabel 18. Ouput Running Solver Optimasi Waktu Minimum

\begin{tabular}{|l|r|r|r|r|}
\hline Total distance = 13.187 & Start node & End node & Distance & $\begin{array}{r}\text { Curnulative } \\
\text { Distance }\end{array}$ \\
\hline Eranch 2 & 1. & 3. & 1. & 1. \\
\hline Eranch 8 & 3. & 6. & 8.66 & 9.66 \\
\hline Eranch 11 & 6. & 7. & 3.527 & 13.187 \\
\hline
\end{tabular}

Dari tabel di atas tampak bahwa hasil urutan tahapan pekerjaan pengecoran adalah cabang 2-8 - 11 atau tahap A-C-F-G, dengan lama waktu 13,187 hari, Hal ini menunjukkan persamaan persis dengan hasil perhitungan pemrograman dinamik, karena digit angka yang sedikit.

\section{PENUTUP}

Di dalam manajemen proyek konstruksi faktor biaya dan waktu menjadi variabel yang sangat penting. Visi apa yang ingin dicapai oleh sebuah kontraktor dalam setiap pelaksanaan, apakah biaya yang minimum atau waktu yang minimum. Secara teori kedua nilai harapan ini tidak dapat dicapai kedua-duanya, sebab waktu yang cepat identik membutuhkan biaya yang mahal, sebaliknya biaya yang murah akan membuat proyek selesai dalam waktu yang lama. Maka tentang keputusan tersebut, kontraktorlah yang menentukan pilihan. Namun yang jelas, aspek manfaat jangan sampai terabaikan, artinya bermanfaat untuk diri sendiri dan orang lain, agar usaha dan segala aktivitas kita diridloi Allah swt. Ada banyak metode telah dikembangkan dan digunakan oleh para kontraktor dalam melaksanakan proyek fisiknya agar berhasil dengan optimum. Optimum maksudnya biaya yang minimum atau waktu yang pendek. Aplikasi formula matematika dapat diterapkan di berbagai persoalan dan mampu diterjemahkan dalam berbagai bidang, termasuk urusan optimasi metode pelaksanaan proyek. Dari sekian banyak pemodelan matematika, salah satunya adalah pemrograman dinamik. Program ini menyelesaikan persoalan secara berurutan saling terkait, baik proses maju maupun mundur. Dari analisis metode yang dilakukan dengan program dinamik, ternyata optimasi berjalan sangat efektif dan relatif singkat, sehingga sang kontraktor cepat dalam mengambil keputusan, dengan tingkat resiko yang kecil. Hal ini tampak jelas pada optimasi metode pengecoran plat pada gedung Green House Jurusan Biologi UIN Maliki Malang. Walau sederhana studi kasus ini mencoba mempraktikkan program dinamik 
dalam metode pelaksanaan proyek konstruksi. Dan tidak menutup kemungkinan program dinamik tersebut dapat diterapkan pada contoh kasus lain di bidang konstruksi yang rumit dan kompleks.

\section{DAFTAR PUSTAKA}

[1] Aminudin. 2005. Prinsip-Prinsip Riset Operasi. Jakarta : Erlangga

[2] Hafidhuddin, Didin, dan Tanjung, Hendri. 2005. Manajemen Syariah dalam Praktik. Jakarta : Gema Insani
[3] Mulyono, Sri. 2004. Riset Operasi Edisi Revisi. Jakarta : Penerbit Fakultas Ekonomi UI.

[4] Soeharto, Iman. 1999. Manajemen Proyek (Dari Konseptual Sampai Operasional) Jilid 1. Jakarta : Erlangga.

[5] Soeharto, Iman. 2001. Manajemen Proyek (Dari Konseptual Sampai Operasional) Jilid 2. Jakarta : Erlangga.

[6] Taha, A Hamdy. 1997. Riset Operasi : Suatu Pengantar alih bahasa Daniel Wirajaya. Jakarta : Binarupa. 